\title{
In the Aftermath of Genocide
}





\section{In the Aftermath of Genocide}

Armenians and Jews in Twentieth-Century France

Maud S. Mandel

Duke University Press Durham and London 2003 
(C) 2003 Duke University Press

All rights reserved

Printed in the United States of America on acid-free paper $(9$ Typeset in Quadraat by Tseng Information Systems, Inc.

Library of Congress Cataloging-in Publication Data appear on the last printed page of this book. 
To Ruth and Barrett Mandel For listening 
